\title{
COVID-19 immunity and vaccines: what a pharmacist needs to know
}

\author{
Rula M. Darwish*๑
}

\begin{abstract}
COVID-19 vaccines are being produced using different platforms by different companies, some of which are entering Phase 3 and 4 trials. Due to the pandemic, this production has been accelerated, which leaves a window for speculation on the method of production and safety. Pharmacists are familiar with vaccination; however, COVID-19 vaccines are still new and further work is needed to clarify many aspects, including side effects, methods of storage, and number of doses. Prioritization of vaccination has been implemented to a certain extent, but no clear strategy is available. A comprehensive overview on immunity and immunological principles for the design of COVID-19 vaccine strategies is provided in this narrative review and the current COVID-19 vaccine landscape is discussed, in addition to exploring the principles for prioritization of vaccination using data from articles available in PubMed and from health organizations. Pharmacists should have a better understanding of COVID-19 vaccines and their manufacture. This would also allow better counseling of the public on COVID 19, immunization, and explaining prioritization basis and vaccination programs.
\end{abstract}

Keywords: COVID-19; coronavirus; pharmacist; SARS-CoV-2; vaccines

The first report on a previously unknown virus causing several pneumonia cases came from Wuhan, China on December 31, 2019, after which it was discovered worldwide and became a global pandemic [1]. The World Health Organization (WHO) considered the outbreak as a "public health emergency of international concern" on January 30, 2020. On February 11 , the atypical respiratory disease caused by the virus now known as severe acute respiratory syndrome (SARS)-CoV-2, a species of coronavirus, was named COVID-19, short for coronavirus disease 2019, and was officially declared a pandemic on March 7, 2020 [2]. There were 2 outbreaks of coronavirus disease before COVID-19; these include the first, a SARS virus, which is believed to have emerged late in 2002 in Guangdong province in China (now named SARS-CoV-1); the second was the Middle-East respiratory syndrome coronavirus (MERS-CoV) first reported in 2012 in Saudi Arabia [3]. The COVID-19 pandemic not only caused a health crisis, but also collateral damage to global economies and many professional business and economic sectors due to governmentally compulsory lockdowns. To date (March 2021), there have been over 118,268,575 confirmed cases of COVID-19, including 2,624,677 deaths reported by WHO [4]. In response to this pandemic, new strategies have been adopted, which include tracking the pandemic, new or so-called "social" distancing, and other ways to mitigate transmission, which have, to a certain extent, prevented most people from being infected.

*Correspondence to: Rula M. Darwish, Department of Pharmaceutics and Pharmaceutical Technology, School of Pharmacy, The University of Jordan, Aljubeiha, Amman 00962, Jordan, email: rulad@ju.edu.jo

Department of Pharmaceutics and Pharmaceutical Technology, School of Pharmacy, The University of Jordan, Aljubeiha, Amman 00962, Jordan

כ Open Access. ๑ 2021 Darwish, published by Sciendo. (G) BY-NC-ND This work is licensed under the Creative Commons Attribution NonCommercial-NoDerivatives 4.0 License. 
However, these strategies do not provide immunity to SARS$\mathrm{CoV}-2$ and thus leave individuals susceptible to successive waves of infection, especially healthcare workers, the elderly, and those with underlying health conditions $[1,5,6]$. It is accepted worldwide that providing safe and effective vaccines with a global vaccination program is inevitably required for the world to return to its normal prepandemic state [7]. The WHO criterion for approval for COVID-19 vaccine development is to have enough supply of approved vaccines to the global market aiming to end the pandemic.

Since the outbreak of this pandemic began, scientists and researchers worldwide have raced to develop COVID-19 vaccines, with at least 270 vaccine candidates currently in preclinical and clinical development [7]. However, it is a difficult task to choose between different vaccine strategies because the nature of protective immune responses to SARS$\mathrm{CoV}-2$ is not fully understood. That is probably why various vaccine platforms and strategies are being developed simultaneously. Moreover, a new pandemic vaccine development model has been introduced that squeezes the development timeline from $10-15$ years to $1-2$ years [8] in response to the urgent need for a vaccine (Figure 1). Nevertheless, there remains great ambiguity on what constitutes a safe and effective COVID-19 vaccine strategy. This race to find a vaccine in a short time might affect the desired outcome for first marketing approval [9]. The efforts and expertise of all healthcare workers are needed at this time of the pandemic. Pharmacists are critical members of the healthcare provider team that is responsible for the welfare of patients and the public. Their role in vaccination is diverse; they can be involved in the development, production, quality control, and administration [10-12]. Thus, they should be equipped with the information required to understand the principles of all aspects of the vaccines, including their production, storage, and administration. The aim of this narrative review is to provide a comprehensive overview of the immunological principles for COVID-19 vaccine design strategies and discuss the current COVID-19 vaccine landscape, focusing on their potential and shortcomings, and discussing prioritization policies that could be adopted for vaccine administration. This would equip the pharmacist with the required information to ensure that COVID-19 vaccines are appropriately handled, stored, and administered.

\section{Methodology and search strategy}

A search of electronic databases was conducted. Articles relevant to COVID-19 vaccines, their production, immunity, and policies for prioritization of vaccination mostly published in 2020-2021 were reviewed from Scopus, PubMed, and Google

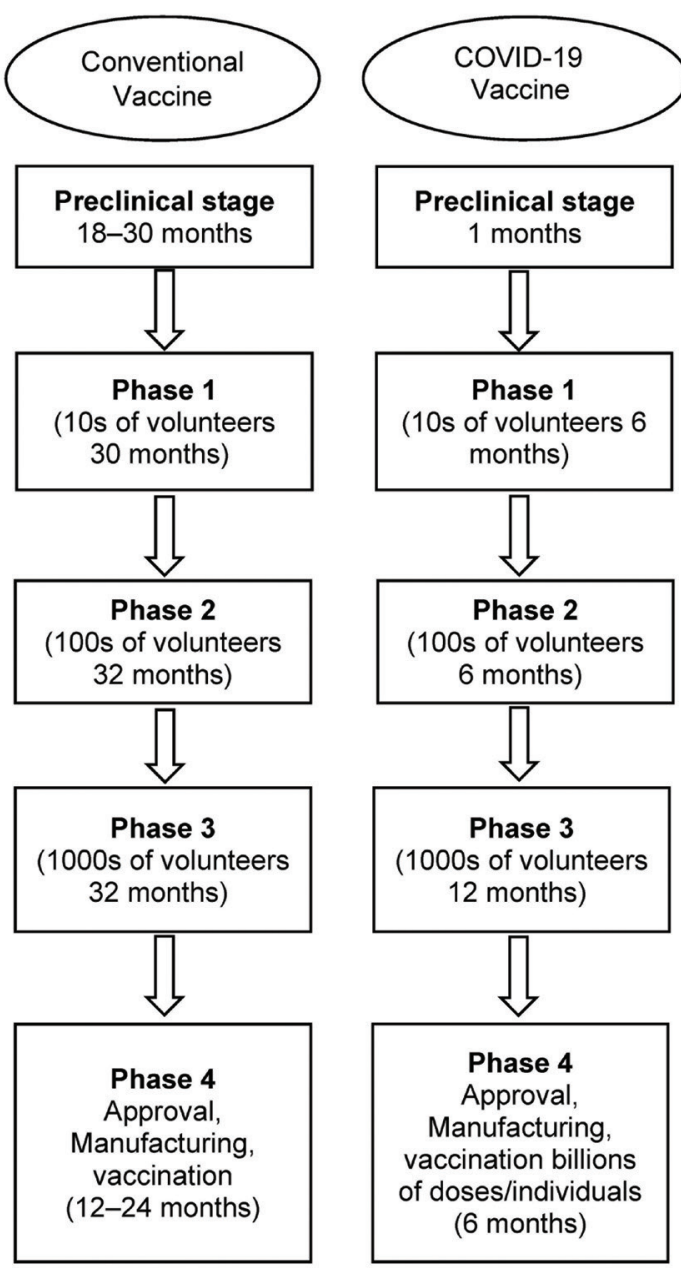

Figure 1. Different stages of clinical trials for conventional vaccines by comparison with COVID-19 vaccines.

Scholar using the following keywords: "COVID-19" OR "COVID-19 immunization" OR "COVID-19 vaccination," and for policies for "vaccine prioritization". An article was excluded if it met any of the following criteria: duplicates or no English abstract. The selected articles were retrieved and assessed for relevance. Review articles were included if related and citations were made as necessary.

\section{Immunity and vaccination}

Vaccines are considered to be a particularly important public health intervention as they protect from diseases and prevent community transmission. However, it is important to understand that this only happens if the vaccine works efficiently and safely. COVID-19 is new to humans and until now the protective immune responses are not fully understood; thus, which vaccine strategies will be effective remain unclear. 


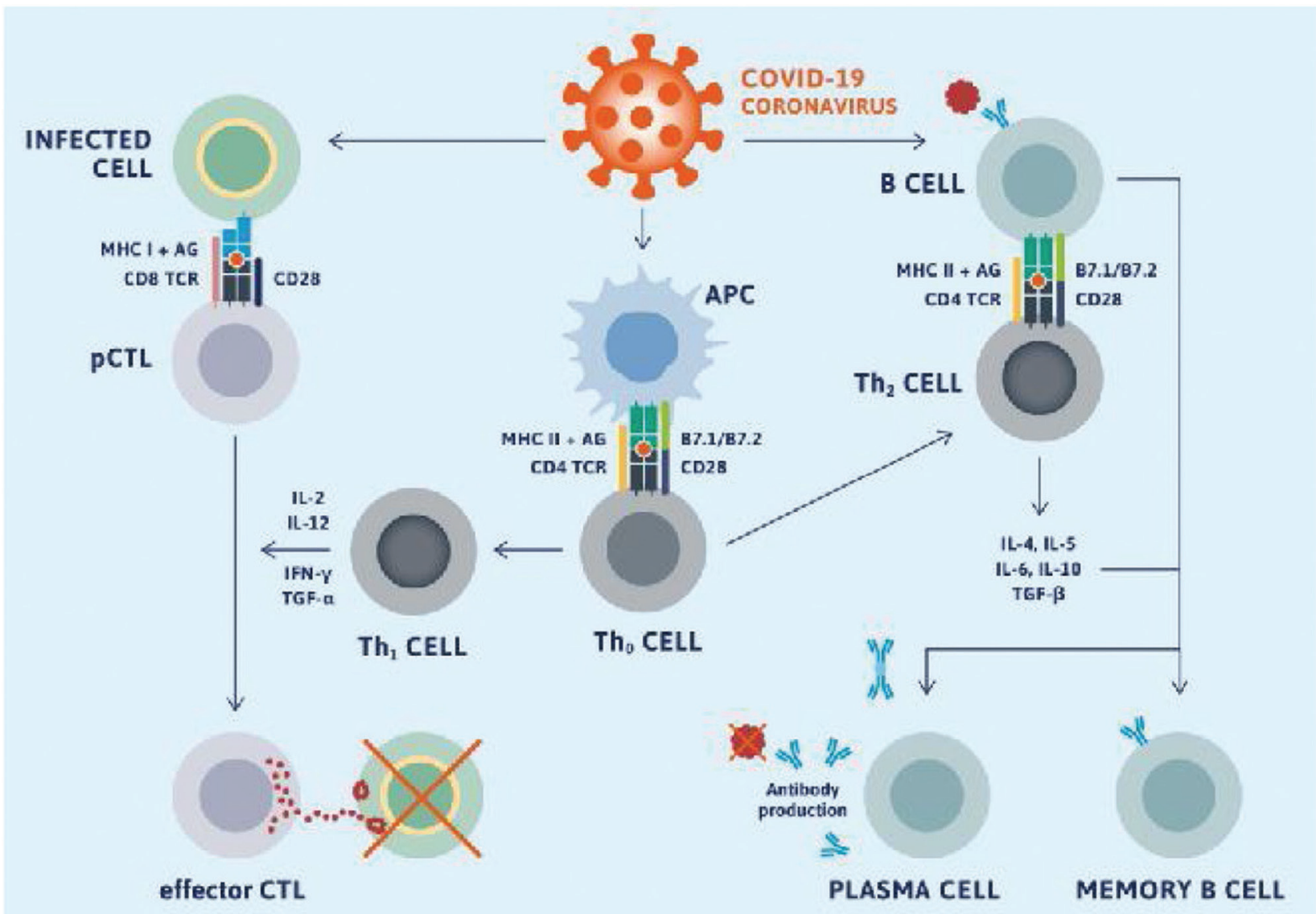

Figure 2. Adaptive immune response produced by SARS-CoV-2 (reproduced from Ref. [13] with permission). AG, antigen; APC, antigen-presenting cell; CTL, cytotoxic T-lymphocyte; IFN, interferon; IL, interleukin; MHC, major histocompatibility complex; TCR, T-cell receptor; TGF, transforming growth factor.

This justifies the diverse directions and platforms followed to develop vaccines. There is a lack of clarity about what may be considered as a safe and at the same time an immunologically effective COVID-19 vaccine strategy. It is also important to define what the successful endpoints in vaccine efficacy testing are and the expectations from the global vaccine effort.

\section{Vaccine-induced immunity}

Understanding the natural immune response to SARS-CoV-2 is important for developing effective vaccine and therapeutic strategies (Figure 2) [13], in particular, an understanding of the differences in immune responses between asymptomatic, mild, and severe cases as well as early and late stages of infection variations, and why the elderly are more susceptible to COVID-19 than the young. It is estimated that $40 \%-75 \%$ of infections may be mild or asymptomatic [14, 15]. Asymptomatic persons may have a significantly longer duration of viral shedding than their symptomatic equals and seem to develop low levels of antibody-mediated immunity [16]. Vaccine-induced protective immunity might differ from natural immunity owing to the immune-evasion strategies of the virus. The primary site of infection of SARS-CoV-2 is the respiratory tract $[17,18]$, where the virus interacts with angiotensin-converting enzyme 2 (ACE2) receptors and probably causes dysregulated inflammatory responses [19, 20]. In severe cases of COVID-19, there is a significant increase in the numbers of inflammatory monocytes and neutrophils in the blood, in addition to an increase in $\mathrm{CD} 14^{+}$and $\mathrm{CD} 16^{+}$ monocyte-derived macrophages in the airway, and increased systemic levels of inflammatory cytokines and chemokines $[21,22]$. Thus, failure to control SARS-CoV-2 infection in its early stages may result in a high viral burden and dysregulated, potentially lethal, inflammatory responses and immunopathology, including acute respiratory distress syndrome. This is probably why the elderly and those with comorbidities may be particularly susceptible to COVID-19, owing to immunosenescence and their vulnerability to support exaggerated inflammatory responses. 


\section{Humoral immunity}

The antibodies IgM and IgG are detectable within 1-2 weeks after the onset of symptoms in most individuals infected with SARS-CoV-2 [23]. High levels of neutralizing antibodies, which are associated with T-cell responses, in particular by $\mathrm{CD}^{+} \mathrm{T}$ cells, have been observed in convalescent individuals $[24,25]$. The magnitude of antibody responses may be positively correlated with the disease severity [26]. This would explain why antibody responses decrease within weeks after infection in most people infected with SARS-CoV-2. The degree of the neutralizing antibody response in asymptomatic individuals is smaller than in symptomatic individuals and decreases faster $[16,27,28]$. The main target of the neutralizing antibodies to coronaviruses is the spike (S) protein, which is composed of S1 and S2 domains. The S1 domain is membrane distal and binds to the cellular ACE2 receptor, while the $\mathrm{S} 2$ domain is membrane proximal and has a role in membrane fusion [29]. It is noteworthy that the $\mathrm{S}$ proteins of SARS-CoV-1 and SARS-CoV-2 are $88 \%$ identical and both bind to ACE2 with high affinity [29]. This means that certain monoclonal and polyclonal antibodies for the S protein of SARS-CoV-1 can cross-neutralize SARS-CoV-2 [29]. High titers of antibodies are generated against nucleoprotein $(\mathrm{N})$ during the natural immune responses; this is the most abundant viral protein in SARS-CoV-2 [30]. The extent of the antibody responses to SARS-CoV-2 is not yet fully understood; however, previous studies of patients with SARS-CoV-1 infection found a substantial decrease in neutralizing antibody titers between 1 year and 2 years after infection. Currently, there is no immune correlation of protection for SARS-CoV-2 or other human coronaviruses. Therefore, it is uncertain what titer of neutralizing antibodies is sufficient to confer protection against infection and for what duration this level of protection will remain. Such correlation is essential for guide the development of effective COVID-19 vaccines.

\section{T-cell-mediated immunity}

Although many successful human antiviral vaccines depend largely on the antibody responses, both antibody-mediated and T-lymphocyte (cell)-mediated immunity are essential for effective protection against SARS-CoV-2 [31, 32]. It is well known that help from $\mathrm{CD} 4^{+} \mathrm{T}$ cells is important for optimal antibody responses and that $\mathrm{CD} 8^{+} \mathrm{T}$ cell activation is important for host defense. Moreover, cytotoxic $\mathrm{CD} 8^{+} \mathrm{T}$ cells are crucial for viral clearance when neutralizing antibody-mediated protection is incomplete $[33,34]$. The incubation or presymptomatic period of SARS-CoV-2 infection is similar to that of SARS and MERS in that it is associated with virus-mediated innate immune suppression and delayed activation of $\mathrm{T}$ cells, particularly $\mathrm{CD} 8^{+}$ $\mathrm{T}$ cells $[35,36]$. It seems that people who have recovered from COVID-19 have high levels of both neutralizing antibodies and T cells, and those with mild cases of COVID-19 have greater numbers of memory $\mathrm{CD} 8^{+} \mathrm{T}$ cells in the respiratory tract than those with severe cases. The induction of such lung tissue-resident memory $\mathrm{T}$ cells $\left(\mathrm{T}_{\mathrm{RM}}\right)$ depends on the route of vaccination. Respiratory mucosal vaccination results in strong lung $\mathrm{T}_{\mathrm{RM}}$ cell responses, but parenteral vaccination does not. The airway $T_{R M}$ cells stimulated by respiratory mucosal vaccination gave strong protection against SARS-CoV infection [37]. Less severe cases of SARS are associated with enhanced induction of a $T$ helper $\left(T_{h}\right) 1$ cell response [38], while $\mathrm{T}_{h} 2$ cell responses have been associated with enhancement of lung disease following infection in hosts vaccinated parenterally with inactivated SARS-CoV vaccines. This implies that COVID-19 vaccine-induced $T_{R M}$ cells should have a $T_{h} 1$ celllike phenotype. These findings strongly support the inclusion of T-cell responses in the COVID-19 vaccine design [31, 32], especially because data suggest that T-cell-mediated immunity is a more reliable correlate of vaccine protection than antibody titers in the elderly [39].

\section{Possibility of cross immunity}

There is some evidence that indicates that $\mathrm{CD}^{+} \mathrm{T}$ cells in some healthy individuals not exposed to SARS-CoV-2 recognize the SARS-CoV-2 S protein and sometimes other than $\mathrm{S}$ protein $[25,40]$. This suggests the possibility of crossreactivity between $\mathrm{CD}^{+}{ }^{+} \mathrm{T}$ cells specific for SARS-CoV-2 and $\mathrm{CD} 4^{+} \mathrm{T}$ cells specific for human common cold coronaviruses, and thus cross immunity.

\section{Rationale for vaccine development}

Vaccines are biological preparations that prepare the natural defenses of the body to recognize and resist the viruses they target. Usually, vaccine development occurs in 3 distinct stages: Stage 1, which involves research and development (R\&D) for platform selection, Stage 2 that is concerned with designing targets (whether that might be selection of an RNA sequence and decisions on nucleoside substitutions, or decisions on how to create a live-attenuated viral preparation), and Stage 3, which involves preclinical testing in vitro using cell culture and in vivo using animals. After the vaccine proves successful in these early stages, it may enter the clinical trials. 


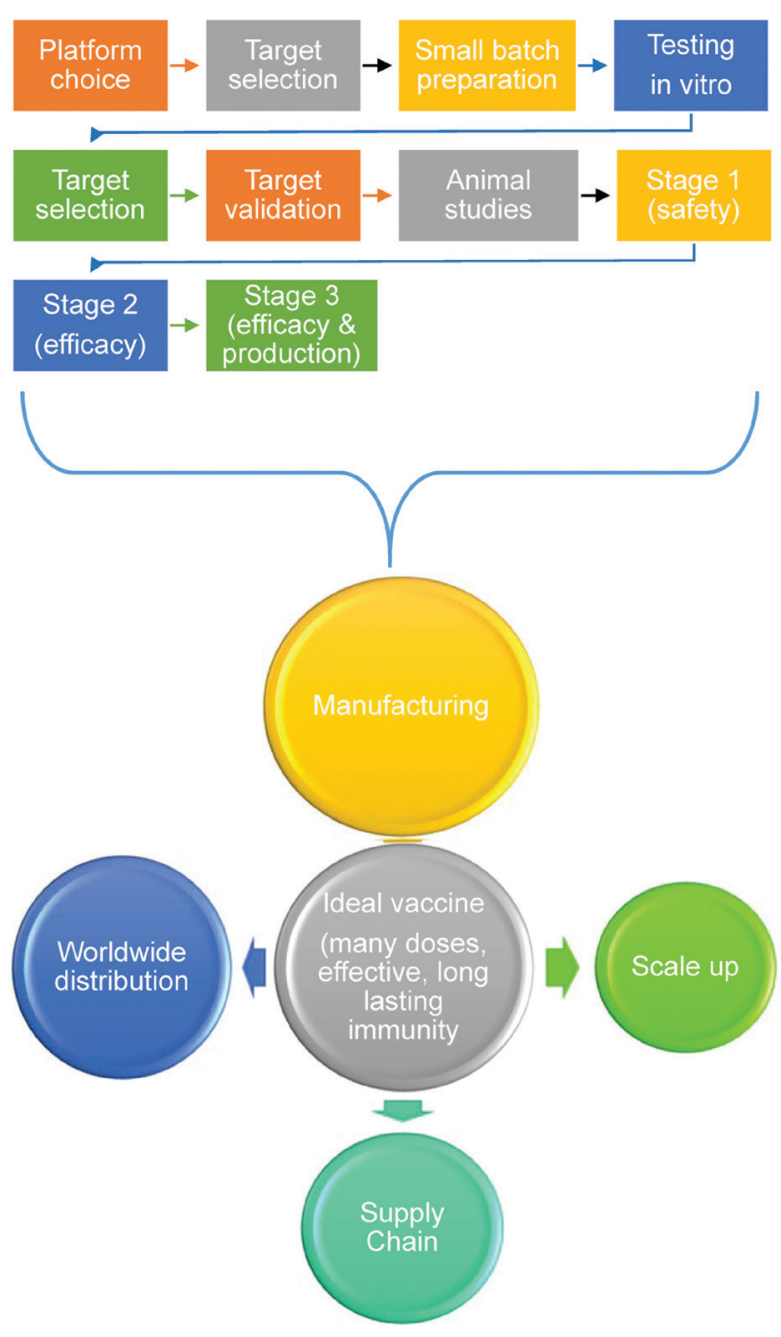

Figure 3. Stages of vaccine development.

In the case of SARS-CoV-2 R\&D, some of the animal models used include transgenic mice that overexpress the spike-binding protein ACE2, and Syrian hamsters, ferrets, and nonhuman primates. If encouraging results are apparent in the preclinical phase, the candidate vaccine is transferred to the second phase, that is, the clinical phase. This involves testing in human volunteers in the 3 stages of clinical trials (Phases 1, 2, and 3). Due to the pandemic nature of COVID19 , the first 2 phases are both being pursued simultaneously under approvals with potential for emergency use authorizations (Figure 1). Only when vaccine safety and efficacy is achieved in human volunteers, the logistical operations (Phase 4) would be accelerated to guarantee worldwide distribution. Vaccine candidates that do not achieve satisfactory results in clinical trials are dropped from further development (Figure 3).

\section{Vaccine design}

The major elements for vaccine design are the selection of appropriate antigens, vaccine platforms, and vaccination routes and regimen.

\section{Vaccine platform choice}

It is very important that the platform choice determines the relative immunogenic strength of vaccine-derived viral antigens, the nature of protective immunity, and whether an adjuvant is required. These traits subsequently determine the suitability of a vaccine for a specific route of vaccination, and whether a booster vaccination regimen is required to increase vaccine-mediated protective immunity and durability [41]. Stricter safety testing is applied for selection of live attenuated viral vaccines or for vaccinations that are administered via a respiratory mucosal route [41].

\section{Selection of SARS-CoV-2 antigens}

The infectious virion protein is composed of structural proteins including the spike (S), $\mathrm{N}$ protein, matrix (M) protein, and envelope (E) protein [41]. The $\mathrm{N}$ protein covers the positive-stranded RNA genome and is enclosed in a lipid envelope obtained from the host cell membrane, into which the other three proteins (, , M, and E) are embedded. For SARS-CoV, only antibodies targeting the $\mathrm{S}$ protein can neutralize the virus and prevent infection [42]. That explains why all SARS-CoV-2 vaccines in development include at least a portion of the $\mathrm{S}$ protein. Non-neutralizing antibodies to the $\mathrm{S}$ protein and the other exposed proteins ( $\mathrm{E}$ and $\mathrm{M}$ ) are processed because of their possible role in antibody-dependent enhancement (ADE), which results when vaccine-induced non-neutralizing or weakly neutralizing antibodies bind to newly infecting virus, and promotes virus uptake into host cells via Fc $\gamma$. Moreover the inclusion of other structural $(\mathrm{N})$ or nonstructural proteins, or both, as vaccine antigens may help to create a more balanced response involving both humoral and T-cell-mediated immunity.

\section{Vaccine platforms}

These include live attenuated virus, recombinant viralvectored vaccines that are bioengineered to express target pathogen antigens in vivo, inactivated virus, protein subunit vaccines, virus-like particles (VLPs), and nucleic acid-based 
(DNA or mRNA) vaccines. Effective vaccines should have 2 major components: antigens from the targeted pathogen, and an infection signal that alerts and activates the host immune system. Live attenuated vaccines provide both of these components; on the other hand, nonviral vaccine platforms provide the antigens, but need the addition of adjuvants, which act as artificial signals to alert the immune system. Usually, nonviral vaccine platforms necessitate multiple vaccinations to induce protective immunity, while live virus-based vaccines do not need more than one shot to provide immunity. The inclusion of an adjuvant and repeated administration is required for inactivated virus vaccines to provide the desired effect in many cases [43].

\section{Vaccination routes}

The route of vaccination is a major aspect of vaccine strategies $[44,45]$. This is especially important for mucosal pathogens like SARS-CoV-2, which requires both innate and adaptive cellular immunity for optimal protection. The asymptomatic or presymptomatic period of COVID-19 (2-12 days) is likely to require all of the immune protective elements within the respiratory mucosa [19]. Parenteral vaccination induces protective IgG antibodies, which readily appear in the respiratory mucosa; however, this route of vaccination is unable to efficiently induce mucosal $\mathrm{IgA}$ antibodies or $\mathrm{T}_{\mathrm{RM}}$ cells in the lungs [44, 46]. By contrast, the respiratory mucosal route of vaccination can not only induce antibodies and $\mathrm{T}_{\mathrm{RM}}$ cells in the respiratory mucosa, but also macrophagemediated trained immunity. Recombinant viral-vectored vaccines are highly effective and safe for respiratory mucosal vaccination [45]. Protein subunit and nucleic acid vaccines from inactivated virus cannot be administered by the respiratory mucosal route because there are special requirements for potentially unsafe immune adjuvants and repeated delivery. It is not yet completely clear which COVID-19 vaccine strategy will be used or for how long the vaccine-induced protection may last in humans; thus, it remains possible that a prime-boost vaccination regimen will be required to sustain protection.

\section{Suppressive factor of efficacy of anti-SARS-CoV-2 vaccine}

Immune deficiency is a risk factor for anti-COVID-19 vaccine efficacy, particularly in the elderly, and is associated with agedependent humoral and immune cell alterations, immunosenescence, and malnutrition [47]. Moreover, current or even past treatments, especially with immunosuppressive drugs, may influence the effectiveness of vaccines in both the elderly and children, mostly in immunocompromised individuals [48-50]. Socioeconomic status is another risk factor associated with a higher viral mortality in developing countries than residence in developed countries [51,52]. The global obesity prevalence among adults and children is also a risk factor for antiSARS-CoV-2 vaccine inefficacy, resulting from higher levels of IL-6 together with decreased IgG concentrations [53]. Respiratory tract infections such as complicated pneumonia and parasitic infections can also affect the immune response to anti-SARS-CoV-2 vaccination [54].

\section{Vaccine safety}

In normal situations, the safety of the vaccine is initially assessed in laboratory studies with mice or rabbits; then, after assuring safety in animals, tests begin in humans, and the number of test participants gradually increases [55]. After the preclinical stage, the vaccine enters Phase 1, where it is given to a small group (10-100) of healthy volunteers (Figure 1) [56]. The main aim is to make sure that the vaccine is safe for humans rather than to test whether it can protect against the disease. A vaccine that passes Phase 1 trials will then enter a Phase 2 trial, in which it is administered to a larger group of trial participants $(100-1,000)$, and then Phase 3 to an even larger group (1,000-100,000), after which comes Phase 4, which comprises the regulatory approval and licensure $[57,58]$. In certain cases, other studies in adults, children, and the elderly are required. Sometimes, vaccines that show safety when given to a small number of people may show side effects when given to a larger number of people; this may be because the probability of occurrence of rare complications is less when the group of volunteer trial participants is small. It is always essential to monitor continuously to cover complications that occur with delayed effect [59]. During pandemics, these successive studies may be shortened and partly overlapped; however, it is important to follow-up thousands of vaccinated people for several months before the vaccine is approved. If the candidate vaccine caused the immune system to malfunction, it would be considered not appropriate for widespread use and delays in the production process would certainly occur [60].

\section{Vaccine manufacturing and regulation}

Manufacturers of a new vaccine must ensure that each vaccine produced is of consistent quality after repeated testing. It 
must be borne in mind that vaccine manufacturing is a biological process; thus, some batches of vaccines might fail for reasons that are unclear, and this would delay production. The investigator must provide proof that the vaccine has sufficient indications of protection and is safe for the individuals tested. Institutional research ethics committees must review clinical trial plans before initiating each stage of the human testing process, and authorities such as the U.S. Food and Drug Administration must supervise the entire vaccine development process before approving it for general use. These approvals usually take several weeks or months [61]. The time for such approvals can be shortened in the event of a pandemic, but many potential COVID-19 vaccines use new technologies, so regulators may not be able to depend on previous experience of related vaccines to quicken the process. The target time given to developers of COVID-19 vaccines is to produce a vaccine within $12-18$ months, which is short when compared with the usual 15-20 years. Many scientific research groups are currently working on the development of a COVID-19 vaccine and following several different approaches. This is being encouraged because most vaccines entering clinical trials might fail due to safety or efficacy reasons. There are a few important traits that need to be addressed for the ideal candidate COVID-19 vaccines and these include easy administration of the vaccine with preference for the oral or intranasal route and single-dose application, ease of production and scaling-up when approved, and the ability to store in attainable storage conditions with the possibility of long-term storage to facilitate logistics particularly in underprivileged nations that usually have inadequate supply and cold chain capabilities (Figure 3).

\section{Major COVID-19 vaccine candidates}

At the end of March 2021, researchers were testing 88 vaccines in clinical development and at least 184 vaccines were under active preclinical investigation [7].

\section{Types of vaccines}

\section{Live attenuated viral vaccines}

It is possible to design attenuated virus strains rationally by mutating or deleting virulence genes. These deletion variant can often replicate to a limited extent in host cells, but have no ability to cause disease in vivo. Coronaviruses have several genes that are not required for replication and that can be deleted, leading to their attenuation in vivo. Deletion of various nonstructural proteins, and the structural E protein, has been used as a strategy to engineer vaccine strains of several zoonotic and veterinary coronaviruses $[62,63]$. Currently, there are 3 attenuated SARS-CoV-2 vaccines generated by codon deoptimization under preclinical development, by Mehmet Ali Aydinlar University in Turkey, Codagenix and Serum Institute of India, and Indian Immunologicals, and Griffith University [7].

Concerns in relation to live attenuated viral vaccines. As with many live attenuated vaccines, reversion of the phenotype has been reported [64]. Thus, to produce an attenuated strain of a pathogen for use as a vaccine, it should demonstrate its inability to revert genetically to become pathogenic. This is very challenging in the case of coronaviruses because they are known to recombine in nature [65], which means an attenuated vaccine strain could recombine with wild coronaviruses to restore a pathogenic strain.

\section{Inactivated viral vaccines}

These types have some shortcomings in relation to the immune response and safety concerns basically related to the adjuvants. Moreover, they express a wide range of their viral antigens, including surface antigens with epitope conformations that can induce conformation-dependent antibody responses $[66,67]$. These types of vaccines are usually prepared by physical or chemical inactivation of the virus and have been used successfully in humans (e.g., vaccines against polio, hepatitis A, and influenza) $[68,69]$. In a pandemic situation, these inactivated viruses can be generated quickly and scaled-up by the use of well-established infrastructure and methods [70].

One of the most advanced candidates to date with published preclinical results is CoronoVac (formerly PiCoVacc), an inactivated SARS-CoV-2 and alum-adjuvant vaccine developed by Sinovac Biotech in China [71]. Early trials were conducted in rhesus macaques and were found to protect against SARS-CoV-2, with reduced viral titers and immunopathology associated with antibodies to $\mathrm{S}$ protein and the nucleocapsid [71]. It was shown to have a low rate of adverse effects, which was not different from placebo [73]. Another inactivated virus candidate is BBIBP-CorV, which is developed by Sinopharm (P.R. China state-owned) and was tested in a variety of animal models, with good efficacy in nonhuman primates [72]. There were no serious adverse effects recorded, and the majority of trial participants $(>95 \%)$ seroconverted with amounts of neutralizing antibody in the various trials [73]. However, i should be noted that these observations were made in short-term studies and as such should be interpreted with caution. In the Phase 3 trials, Sinopharm was 
Table 1. Advantages and disadvantages of various vaccine platforms, selected vaccines that have entered Phases 3 and 4, their developers, route of administration, and the number of doses required to induce the required immune response

\begin{tabular}{|c|c|c|c|c|c|c|c|}
\hline $\begin{array}{l}\text { Vaccine } \\
\text { platform } \\
\text { description }\end{array}$ & Advantages & Disadvantages & Developers & $\begin{array}{l}\text { Type of } \\
\text { candidate vaccine }\end{array}$ & $\begin{array}{l}\text { Route of } \\
\text { administration }\end{array}$ & $\begin{array}{l}\text { Number } \\
\text { of doses }\end{array}$ & Phase \\
\hline \multirow[t]{5}{*}{$\begin{array}{l}\text { Inactivated } \\
\text { virus }\end{array}$} & \multirow{5}{*}{$\begin{array}{l}\text { - The pathogen } \\
\text { is inactivated } \\
\text { - Easy transport } \\
\text { and storage }\end{array}$} & \multirow{5}{*}{$\begin{array}{l}\text { - Pathogen needs } \\
\text { to be processed in } \\
\text { large quantities } \\
\text { - The antigen } \\
\text { immunogenicity } \\
\text { can be affected by } \\
\text { the inactivation } \\
\text { process } \\
\text { - Antibody titers } \\
\text { reduce over time } \\
\text { - Do not produce } \\
\text { cellular responses } \\
\text { Need several } \\
\text { booster doses }\end{array}$} & $\begin{array}{l}\text { Sinovac } \\
\text { Research and } \\
\text { Development }\end{array}$ & $\begin{array}{l}\text { CoronaVac; Inactivated SARS- } \\
\text { CoV-2 COVID-19 vaccine }[7,74]\end{array}$ & IM & 2 & 4 \\
\hline & & & $\begin{array}{l}\text { Sinopharm + } \\
\text { China National } \\
\text { Biotec Group + } \\
\text { Wuhan Institute } \\
\text { of Biological } \\
\text { Products }\end{array}$ & $\begin{array}{l}\text { Inactivated SARS-CoV-2 } \\
\text { COVID-19 vaccine }[7,72]\end{array}$ & IM & 2 & 3 \\
\hline & & & $\begin{array}{l}\text { Sinopharm + } \\
\text { China National } \\
\text { Biotec Group }+ \\
\text { Beijing Institute } \\
\text { of Biological } \\
\text { Products }\end{array}$ & $\begin{array}{l}\text { Inactivated SARS-CoV-2 } \\
\text { COVID-19 vaccine } \\
\text { (Vero cells), BBIBP-CorV } \\
{[7,71,72]}\end{array}$ & IM & 2 & 3 \\
\hline & & & $\begin{array}{l}\text { Institute of } \\
\text { Medical Biology } \\
+ \text { Chinese } \\
\text { Academy of } \\
\text { Medical Sci- } \\
\text { ences }\end{array}$ & $\begin{array}{l}\text { Inactivated SARS-CoV-2 } \\
\text { COVID-19 vaccine } \\
\text { (Vero cells) [7] }\end{array}$ & IM & 2 & 3 \\
\hline & & & $\begin{array}{l}\text { Bharat Biotech } \\
\text { International } \\
\text { Limited }\end{array}$ & $\begin{array}{l}\text { Whole-virion inactivated } \\
\text { SARS-CoV-2 COVID-19 } \\
\text { vaccine, BBV152 (Covaxin) [7] }\end{array}$ & IM & 2 & 3 \\
\hline \multirow[t]{4}{*}{$\begin{array}{l}\text { Viral vector } \\
\text { (nonreplica- } \\
\text { ting) }\end{array}$} & \multirow{4}{*}{$\begin{array}{l}\text { - Able to } \\
\text { induce robust } \\
\text { humoral and } \\
\text { cellular res- } \\
\text { ponses with a } \\
\text { single dose } \\
\text { - Good safety } \\
\text { profile }\end{array}$} & \multirow{4}{*}{$\begin{array}{l}\text { - Some of the can- } \\
\text { didates require } \\
\text { storage at } \leq 20^{\circ} \mathrm{C} \\
\text { - Preexisting } \\
\text { immunity against } \\
\text { a human viral } \\
\text { vector can affect } \\
\text { the immune } \\
\text { responses }\end{array}$} & $\begin{array}{l}\text { AstraZeneca + } \\
\text { University of } \\
\text { Oxford }\end{array}$ & $\begin{array}{l}\text { ChAdOx1-S (AZD1222) } \\
\text { Covishield }[7,41]\end{array}$ & IM & $1-2$ & 4 \\
\hline & & & $\begin{array}{l}\text { CanSino Bio- } \\
\text { logical/Beijing } \\
\text { Institute of } \\
\text { Biotechnology }\end{array}$ & $\begin{array}{l}\text { Recombinant COVID-19 } \\
\text { vaccine (adenovirus type } 5 \\
\text { vector) }[7,76]\end{array}$ & IM & 1 & 3 \\
\hline & & & $\begin{array}{l}\text { Gamaleya } \\
\text { Research } \\
\text { Institute; Health } \\
\text { Ministry of the } \\
\text { Russian Fede- } \\
\text { ration }\end{array}$ & $\begin{array}{l}\text { Gam-COVID-Vac Adeno-based } \\
\text { (rAd26-S + rAd5-S) }[7,74]\end{array}$ & IM & 2 & 3 \\
\hline & & & $\begin{array}{l}\text { (J\&) Janssen } \\
\text { Pharmaceuticals }\end{array}$ & Ad26.COV2.S [7, 78, 79] & $\mathrm{IM}$ & $1-2$ & 3 \\
\hline
\end{tabular}


Table 1. Continued

\begin{tabular}{|c|c|c|c|c|c|c|c|}
\hline $\begin{array}{l}\text { Vaccine } \\
\text { platform } \\
\text { description }\end{array}$ & Advantages & Disadvantages & Developers & $\begin{array}{l}\text { Type of } \\
\text { candidate vaccine }\end{array}$ & $\begin{array}{l}\text { Route of } \\
\text { administration }\end{array}$ & $\begin{array}{l}\text { Number } \\
\text { of doses }\end{array}$ & Phase \\
\hline \multirow[t]{5}{*}{$\begin{array}{l}\text { Protein } \\
\text { subunit }\end{array}$} & \multirow{5}{*}{$\begin{array}{l}\text { - Safety during } \\
\text { production } \\
\text { - Can be safely } \\
\text { administered } \\
\text { to immuno- } \\
\text { suppressed } \\
\text { people } \\
\text { - No infec- } \\
\text { tious agent } \\
\text { handling is } \\
\text { required }\end{array}$} & \multirow{5}{*}{$\begin{array}{l}\text { - Small size of anti- } \\
\text { gens diminishes } \\
\text { their uptake by } \\
\text { APCsa } \\
\text { - Several booster } \\
\text { doses and adju- } \\
\text { vants are needed } \\
\text { - Integrity of the } \\
\text { antigen needs to } \\
\text { be confirmed } \\
\text { - Low immunoge- } \\
\text { nicity } \\
\text { - Do not elicit cellu- } \\
\text { lar responses. } \\
\text { - The production is } \\
\text { limited by antigen } \\
\text { production scala- } \\
\text { bility. }\end{array}$} & Novavax & $\begin{array}{l}\text { SARS-CoV-2 rS/Matrix } \\
\text { M1-Adjuvant (full-length } \\
\text { recombinant SARS CoV-2 } \\
\text { glycoprotein nanoparticle } \\
\text { vaccine adjuvanted with } \\
\text { matrix M) [7] }\end{array}$ & IM & 2 & 3 \\
\hline & & & $\begin{array}{l}\text { Anhui Zhifei } \\
\text { Longcom } \\
\text { Biopharmaceu- } \\
\text { tical + Institute } \\
\text { of Microbio- } \\
\text { logy, Chinese } \\
\text { Academy of } \\
\text { Sciences }\end{array}$ & $\begin{array}{l}\text { Recombinant COVID-19 } \\
\text { vaccine }[7,74]\end{array}$ & IM & $2-3$ & 3 \\
\hline & & & $\begin{array}{l}\text { Sanofi Pasteur } \\
+ \text { GSK }\end{array}$ & $\begin{array}{l}\text { VAT00002: COVID-19 vaccine } \\
\text { formulation } 1 \text { with adjuvant } 1 \\
\text { (S protein (baculovirus } \\
\text { production) }[7,74]\end{array}$ & IM & 2 & 3 \\
\hline & & & $\begin{array}{l}\text { Instituto Finlay } \\
\text { de Vacunas }\end{array}$ & $\begin{array}{l}\text { FINLAY-FR-2 anti-SARS-CoV-2 } \\
\text { vaccine (RBD conjugated to } \\
\text { tetanus toxoid plus } \\
\text { adjuvant) [7] }\end{array}$ & IM & 2 & 3 \\
\hline & & & $\begin{array}{l}\text { Federal Budge- } \\
\text { tary Research } \\
\text { Institution State } \\
\text { Research Center } \\
\text { of Virology and } \\
\text { Biotechnology } \\
\text { "Vector" }\end{array}$ & $\begin{array}{l}\text { EpiVacCorona (EpiVacCorona } \\
\text { vaccine based on peptide } \\
\text { antigens [7] }\end{array}$ & IM & 2 & 3 \\
\hline \multirow[t]{3}{*}{$\begin{array}{l}\text { RNA based } \\
\text { vaccine }\end{array}$} & $\begin{array}{l}\text { - High } \\
\text { scalability } \\
\text { - Quick } \\
\text { design and } \\
\text { development }\end{array}$ & $\begin{array}{l}\text { - mRNA vaccines } \\
\text { display instability } \\
\text { and need storage } \\
\text { at } \leq 20^{\circ} \mathrm{C} \\
\text { - DNA vaccines }\end{array}$ & $\begin{array}{l}\text { Moderna + Nati- } \\
\text { onal Institute } \\
\text { of Allergy and } \\
\text { Infectious Disea- } \\
\text { ses (NIAID) }\end{array}$ & mRNA-1273 $[7,79,80,81]$ & IM & 2 & 4 \\
\hline & $\begin{array}{l}\text { - No infec- } \\
\text { tious agent } \\
\text { handling is }\end{array}$ & $\begin{array}{l}\text { require a special } \\
\text { delivery platform }\end{array}$ & $\begin{array}{l}\text { Pfizer/BioNTech } \\
+ \text { Fosun Pharma }\end{array}$ & BNT162 [7, 79, 82, 83, 84] & IM & 2 & 4 \\
\hline & $\begin{array}{l}\text { required } \\
\text { - Can induce }\end{array}$ & & CureVac & CVnCoV vaccine [7] & IM & 2 & 3 \\
\hline $\begin{array}{l}\text { DNA-based } \\
\text { vaccine }\end{array}$ & $\begin{array}{l}\text { cellular and } \\
\text { humoral } \\
\text { responses }\end{array}$ & & Zydus Cadila & COVID-19 vaccine [7] & ID & 3 & 3 \\
\hline
\end{tabular}

Ad5, human serotype 5 adenovirus; Ad26, human serotype 26 adenovirus; ChAd, chimpanzee adenovirus; COVID-19, severe acute respiratory syndrome (SARS) coronavirus 2 coronavirus (CoV-2) disease 2019; mRNA-1273, novel lipid nanoparticle (LNP)-encapsulated mRNA-based vaccine; IM, intramuscular; S protein, spike protein; RBD, receptor-binding domain; ID intradermal. 
shown to be $79 \%$ effective. A small-sample laboratory-based study, with data released in early February 2021 found that the vaccine provides protection against the South African variant; however, it had a weaker effect by comparison with the protection it provides against the original virus. The vaccine is authorized in China, the United Arab Emirates, Bahrain, Pakistan, Egypt, Morocco, and Hungary, and is also in wide use in Serbia. The other vaccine from China, Coronovac, from Sinovac Biotech, is made of a purified, inactivated coronavirus and it uses an adjuvant from Dynavax, which the California-based company uses in its own hepatitis B vaccine. It was approved for emergency use in China, Mexico, Indonesia, Thailand, Brazil, Turkey, and Chile, among other countries. There are contradicting reports on the efficacy of the vaccine. A trial in Brazil showed the vaccine to prevent hospitalizations and deaths among all participants, was $83.7 \%$ effective in preventing cases that would require medical treatment, and was $50.7 \%$ effective in preventing infections. A small clinical trial in Turkey showed the vaccine to be $91.25 \%$ effective in blocking infections [74].

Concerns in relation inactivated viral vaccines. To obtain the required immune response, inactivated viral vaccines usually require the addition of adjuvant and repeated administration. Alum is one of these widely-used adjuvants; however, its presence makes the vaccine unsuitable for respiratory mucosal delivery [75]. It is noteworthy that protection mediated by intramuscular vaccination with CoronoVac or BBIBP-CorV indicates some mucosal immunity, possibly by the transport of systemic antibodies to the lungs; however, the durability of such immunity remains to be further studied as SARS-CoV-2 challenge was performed 1-4 weeks after vaccination (Table 1) [7, 71, 72]. Inactivated viral vaccines are poor inducers of cytotoxic CD8 ${ }^{+}$ $\mathrm{T}$ cells, which are likely to be required for an effective COVID19 vaccine. Furthermore, studies have reported vaccine-related enhancement of disease, likely involving a $T_{h} 2$ cell response and lung eosinophilia, which may be worsened in aged hosts.

Because alum is known to drive $\mathrm{T}_{\mathrm{h}} 2$ cell-mediated immune the use of $T_{h} 1$ cell-skewing modified alum or other adjuvants may improve safety $[84,85]$.

\section{Recombinant viral-vectored vaccines}

These are based on a replication-deficient viral backbone or an attenuated replication competent viral backbone that is bioengineered to express antigens derived from the target pathogen. This platform has been widely investigated and has a well-established track record for infectious diseases. This is because of its genetic adaptability, safety, and ability to induce strong T-cell responses without the need for an adjuvant
$[86,87]$. There are some viral vectors, such as human serotype 5 adenovirus (Ad5) and chimpanzee adenovirus (ChAd), which require to be administered only once for protection and have natural tropism for the respiratory mucosa, which makes them convenient for respiratory mucosal vaccination [45]. Therefore, recombinant viral vectors are considered to be one of the most common platforms for COVID-19 vaccine development. At present, there are 4 vaccine candidates in clinical trials and 38 under preclinical development (Table 1) [7, 41]. There are two viral platforms in this regard, namely, the nonreplicating vaccines, which are mostly based on Ad5 or modified vaccinia virus Ankara (MVA) that mostly expresses the $\mathrm{S}$ protein or receptor-binding domain (RBD) of SARS-CoV-2, and replication-competent viral vectors that are mainly based on the vaccine strains of other human pathogens or veterinary pathogens. Thus, it will be important to consider whether humans have preexisting immunity against the viral backbone, which can impair the ability of such vaccines to engage the immune system. To avoid this evasion, the use of viral backbones such as ChAd, for which humans have little to no preexisting immunity, is recommended [45].

CanSino Biologics, the Chinese vaccine company, developed Ad5-nCOV, which is designed to induce neutralizing antibodies to SARS-CoV-2 $\mathrm{S}$ protein after intramuscular injection. Three levels of doses of vaccine entered the Phase 1 and 2 clinical trials without providing preclinical data. The highest dose generated unacceptable toxicity and was dropped from the Phase 2 study. The smaller doses induced S proteinspecific neutralizing antibodies in only half of the vaccine recipients. Shortcomings. The vaccine induces both antibody and T-cell responses; however, its potency is reduced by preexisting immunity to Ad5, especially in the elderly [76]. These observations from Phase 1 are confirmed by the Phase 2 study. Although the efficacy of this strategy is questionable, the vaccine is undergoing more advanced trials in China and Canada. Concerns have been expressed that use of an Ad5 vector for immunization against SARS-CoV-2 could increase the risk of HIV-1 acquisition by those who receive such a vaccine [88].

Sputnik V is one of the vaccines in this category, which received approval for emergency use from Russia in August 2020, before the Phase 3 trials, which are now being performed. Moreover, around 40 countries, including Belarus, Iran, Mexico Serbia, Argentina, Algeria, Hungary, Slovakia, and Nicaragua have approved it for emergency use. It is noteworthy that the Gamaleya Institute of Epidemiology and Microbiology, a vaccine developer of the Ministry of Health of the Russian Federation, has signed an agreement in late December 2020 with AstraZeneca to test a combination of the vaccine developed by AstraZeneca and Oxford 
University and the Sputnik V component. The human trials began in mid-February in Azerbaijan and some Middle Eastern countries [74].

Johnson \& Johnson (Janssen Pharmaceuticals) is developing another human adenovirus-based COVID-19 vaccine, known as Ad26-S, which has seroprevalence for Ad26 in humans (Table 1) [7, 77]. The vaccine was $66 \%$ effective overall across several Phase 3 studies worldwide testing a single-dose regimen; however, the efficacy was $57 \%$ in South Africa where an extremely transmissible variant is spreading. The efficacy of the vaccine in preventing severe disease was $85 \%$, and gave complete protection against hospitalization and death [74]. Shortcomings. Ad26 is inherently less immunogenic than Ad5; thus, to ensure effective immunity, repeated vaccination is needed [89-91]. However, when Ad26-vectored COVID-19 vaccine (Ad26.CoV-2.S) was administered parenterally, it showed great protection in a nonhuman primate [92].

Oxford University, UK, and Astra Zeneca are developing one of the most promising and clinically advanced COVID-19 vaccines, which is ChAdOx1 nCoV-19 also known as AZD1222, which recently entered Phase 3 (Table 1) [7]. A study of Phases 1 and 2 of this vaccine reported its safety with production of potent neutralizing antibody in addition to T-cell responses following a single parenteral injection, which are boosted additionally by a second homologous vaccination [93]. A recent report revealed that some European countries temporarily suspended use of the Oxford-AstraZeneca vaccine as a precautionary move after reports of blood clots [94]; however, the UK's regulatory body and the European Medicines Agency (EMA) stated that there is no indication that the vaccination is associated with thromboembolic events.

Shortcomings. Despite its intramuscular delivery, ChAdOx1 nCoV-19 reduced SARS-CoV-2 viral load in the lungs and stopped pneumonia in rhesus macaques, but it did not reduce viral loads in the upper respiratory tract [95]. Moreover, it remains unclear from trials as to what extent both the $\mathrm{CD} 4^{+}$and $\mathrm{CD} 8^{+} \mathrm{T}$ cell subsets were activated. During trials, volunteer participants have experienced mild to moderate injection site pain in addition to mild to severe systemic adverse reactions, which included fatigue chills, malaise, and headache; which was mostly on Day 1, and these symptoms were relieved by paracetamol [93].

Merck and other groups are developing VSV-S, which is a replication-competent COVID-19 vaccine [7, 96]. Merck's vaccine is based on the licensure of its effective VSV-Ebola vaccine, which induces neutralizing antibodies and cellular immunity against Ebola virus surface glycoprotein [96]. Humans have no preexisting immunity to the veterinary virus VSV, but its suitability for respiratory mucosal vaccination is uncertain and its cloning capacity is limited. A single parenteral vaccination with a VSV vector expressing $\mathrm{S}$ protein provides protection against SARS-CoV-2 in both mouse and hamster models [97, 98]. However, the development of this vaccine was discontinued because findings from Phase 1 clinical studies showed that although it was well tolerated, the immune responses were inferior to those reported for other COVID-19 vaccines and those seen following natural infection.

\section{Protein subunit vaccines}

Subunit vaccines initially induce both $\mathrm{CD}^{+} \mathrm{TH}$ cell and antibody responses. This is because, most of these vaccines contain full-length SARS-CoV-2 S protein or portions of it, and this is comparable to the majority of SARS, which had differing levels of efficacy [99-101]. One of the advantages of the subunit vaccines is that they can be designed to focus the immune response toward neutralizing epitopes, in a way that would prevent the production of nonneutralizing antibodies that may promote ADE of disease [102]. Nevertheless, recombinant $\mathrm{S}$ proteins in subunit vaccines could possess improper epitope conformation unless they are produced in mammalian cells [103]. Furthermore, proteins or peptides alone are not immunogenic enough and usually need adjuvants in addition to repeated administration. This platform is generally unsuitable for respiratory mucosal vaccination due to the use of unmodified alum as an adjuvant, which will tilt the immune response toward $\mathrm{T}_{h} 2$ cell-like responses, which is undesirable for host defense against SARS-CoV-2 and may have a role in ADE of disease [76, 104, 105].

At present, there are about 28 COVID-19 subunit vaccines in clinical trials and 70 other candidates under preclinical development as reported by WHO [7]. GlaxoSmithKline and Novavax are developing COVID-19 subunit vaccines using different adjuvants currently entering Phase 3 trials (Table 1) [7]. GSK announced that it could seek emergency authorization in the United States in April 2021, when the results from its 30,000-person Phase 3 trial in the United States and Mexico is completed. According to the company, the vaccine was $89 \%$ effective against a variant first found in the United Kingdom, but only $49 \%$ effective against the South African strain [74].

Shortcomings. There remain some concerns in relation to high levels of S-specific neutralizing antibodies. Other vaccines using recombinant trimeric SARS-CoV-2 spike protein (S) are developed by Clover Biopharmaceuticals in China, University of Queensland in Australia, and Sanofi/GSK collaboration (France/ UK) (Table 1). The companies are currently performing Phase 1 and 2 trials in 440 healthy adults at 11 sites in the United States. 
Preliminary results revealed insufficient immune response in older adults, which was attributed to insufficient concentration of the antigen in the formulation of the vaccine. The companies are now planning a Phase $2 \mathrm{~b}$ trial that will lead to a global Phase 3 trial in April 2021 at the earliest [74].

\section{Virus-like particles (VLP)}

There are a number of commercial vaccines based on VLPs, including hepatitis B and human papillomavirus vaccines [106]. As for the enveloped coronaviruses, VLPs are produced when the viral proteins are expressed in eukaryotic cells [107, 108]. Active budding will then occur from the VLP producer cells, which are structurally identical to the infectious virus, but lack the viral genome and thus are noninfectious. S protein on the surface of VLPs enables them to bind and enter ACE2 ${ }^{+}$ cells in the same manner as the parent virus [109]. The array of S protein on the VLP surface crosslinks B-cell receptors and directly activates them; however, VLPs usually require an adjuvant and repeated administration [106].

To date there are only 3 VLP-based COVID-19 vaccine in clinical trials, and 17 under preclinical development [7]. The vaccines are either produced in vivo from a viral vector that expresses the VLP components (e.g., GeoVax vaccine) or in vitro from producer cells. It is noteworthy to mention that the Canadian company, Medicago, produces its SARS-CoV-2 VLPs from genetically engineered plants and their preliminary findings suggest possible efficacy in inducing neutralizing antibodies in mice [110].

\section{Nucleic-acid-based vaccines}

The major advantage of mRNA vaccines is that they are noninfectious and are synthesized by in vitro transcription, free of microbial molecules. The antigen-encoding mRNA would be complexed with a carrier, such as lipid nanoparticles, and then can be efficiently delivered in vivo into the cytoplasm of host cells for protein translation and post-translational modifications $[111,112]$.

These make mRNA vaccines more advantageous than the other vaccine types, including live attenuated, inactivated, subunit vaccines, and recombinant viral-vectored vaccines in that they are safer and more efficacious, which support their rapid and inexpensive production and repeated vaccination [111]. Shortcomings. In spite of the promising effect of mRNA-based COVID-19 vaccines in early clinical testing, ambiguity regarding their protective efficacy in humans and their suitability for respiratory mucosal delivery remain.
At the end of March 2021 there were 12 mRNA-based COVID-19 vaccines and 104 DNA-based COVID-19 vaccines in clinical trials, and 40 such vaccines (24 mRNA-based and 16 DNA- based vaccines) under preclinical development [7]. Moderna, a biotech company in the USA produced mRNA1273, which encodes a prefusion stabilized SARS-CoV-2 S protein encapsulated in lipid nanoparticles. This vaccine is currently authorized and recommended to prevent COVID-19 [78]. It entered clinical testing even before the release of preclinical data (Table 1) [79]. Data from a Phase 1 clinical trial suggest that low and medium doses of 2 repeated parenteral injections induce strong $\mathrm{S}$ protein-specific antibody responses and a primarily $\mathrm{CD}^{+}{ }^{+} \mathrm{T}$-cell response in most trial participants and are in general safe [80].

Pfizer and BioNTech are also developing an mRNA-lipid nanoparticle vaccine encoding the S protein RBD in humans. A simultaneous Phase 1 clinical trial that compared BNT162b1 with a different Pfizer and BioNTech candidate vaccine, BNT162b2, showed that the BNT162b2, which encodes for $2 \mathrm{P}$-stabilized spike protein rather than trimerized RBD, but uses mRNA in a similar stabilizing formulation, caused fewer systemic reactions than BNT162b1 [81]. The Pfizer vaccine is currently authorized and recommended to prevent COVID19 (Table 1). It developed robust $\mathrm{S}$ protein-specific antibody and $\mathrm{CD}^{+}$and $\mathrm{CD} 8^{+} \mathrm{T}$-cell responses following two repeated parenteral injections $[82,83]$. However, one of the important shortcomings of Pfizer's vaccine is that it must be kept at $-70{ }^{\circ} \mathrm{C}$, and will only remain effective for $24 \mathrm{~h}$ at refrigerated temperatures between 2 and $8^{\circ} \mathrm{C}$.

Plasmid DNA vaccines have several similarities to $\mathrm{mRNA}$ vaccines, including safety and ease of production [113]. However, they differ from mRNA vaccines in that they are poorly immunogenic, requiring addition of adjuvants, and they need to be administered in multiple doses.

Inovio Pharmaceuticals, a biotech company in the United States, is developing a plasmid DNA vaccine expressing SARS-CoV-2 S protein (INO-4800). However, the immunogenicity of this vaccine was studied in mice and guinea pigs, but did not provide any data relating to protection against challenge [114]. Two repeated injections of an $\mathrm{S}$ protein-expressing plasmid DNA vaccine resulted in robust protective immunity in rhesus macaques [115]. Symvivo (Canada) is developing a BacTRL-Spike using DNA plasmid expressing trimeric $\mathrm{S}$ and a hybrid transporter protein within Bifidobacterium longum to be used by oral ingestion of a probiotic capsule and delivered to colonic epithelial cells to prime an immune response via colonic lymphoid tissues. Although probiotics are used extensively worldwide, DNA vaccines are not currently on the market for use in humans and this strategy in particular is not yet validated (Table 1). 


\section{Prioritization for COVID-19 vaccines}

Current vaccine coverage is over 100 million, targeting mainly healthcare workers, essential workers, and the elderly. It is expected that the demand for effective COVID-19 vaccines might be more than the supply; thus, it is important to have a strategy to prioritize their use to ensure the maximum benefits. The Joint Committee on Vaccination and Immunization [116] interim advice suggests that people $>65$ years old, healthcare workers, and individuals in shielding groups should be prioritized for vaccination. However, the advice lacks details and it is highly important that a plan is developed that takes into account evidence of the effect of comorbidities, occupational, and socioeconomic factors on COVID-19 severity [117].

The plan suggested should take into consideration factors associated with high rates of hospitalization and are likely to cause death from COVID-19 like poverty, education, physical crowding, and smoke exposure [118, 119]. In light of this, Hassan-Smith et al. [117] proposed a plan that dictates prioritizing of certain groups, including those with noncommunicable diseases (e.g., diabetes, hypertension, obesity, and cardiovascular disease), high-risk occupational groups, and those working in public facing roles, such as those in security and transport. In addition, socioeconomic factors associated with adverse outcomes in COVID-19 should also be considered, and an effective strategy would include vaccination of those living in overcrowded conditions or in institutions such as care homes [120]. The WHO guidelines indicated the following, which comprises the main categories of priority groups during influenza pandemics: (a) healthcare workers; (b) people working in jobs that are important for public safety; (c) persons at high risk of death and severe complications; and (d) healthy adults and children [121]. However, before implementation of any categorization it is important to explain and announce the objectives and the rationale for the vaccine prioritization concept so as to gain the approval of the public. Ethics committees should be involved in the establishment of the vaccine prioritization concept. Prioritization of healthcare workers may be justified by the 3 rationales: First, to protect them directly because they are at increased risk: second to prevent or minimize transmission to high risk individuals; and third to maintain the integrity of infrastructure and healthcare systems.

\section{Conclusions}

COVID-19 has affected the health system worldwide and urges the need for an effective and safe vaccine. Researchers, developers, and manufacturers are racing to develop these vaccines rapidly resulting in many vaccine candidates, with a few entering Phases 1 and 2, and Phase 3 clinical trials within a relatively short period of 6 months, followed by Phase 4 , which includes regulatory approval and licensure. In doing so, most of the advanced vaccine platforms that have been extensively explored for other infections and cancer are being used $[45,86,87,122]$. The traditional vaccine development timeframe is compressed to 1-2 years, with overlapping preclinical, clinical, and scale-up manufacturing processes occurring in parallel. This rush would result in difficulty in having accurate information about the longevity and quality of vaccine-induced protective immunity. Moreover, it is not easy to compare the effectiveness of various candidates because each vaccine has been studied in isolation. Prioritization is another important issue requiring close attention as vaccines become available. Implementation of clear vaccination programs, which take into account all the vulnerable groups that could be affected and affect others is necessary, especially because there are challenges that remain for resources, manufacturing, and distribution [123].

Author contributions: RMD conceived the idea for this review, designed the study, performed the literature search and data analysis, and drafted and critically revised the work. RMD approved the final version submitted for publication and takes responsibility for the statements made in the published article.

Acknowledgements: No specific grant for this work was received from any funding agency in the public, commercial, or not-for-profit sectors. The author thanks the original authors [13] and Elsevier for their permission to reproduce the image shown in Figure 2.

Conflicts of interest statement: RMD has completed and submitted an International Committee of Medical Journal Editors Disclosure Form for Potential Conflicts of Interest and has no conflict of interest to declare in relation to the present article.

Data sharing statement: No datasets were generated or analyzed during the present study. The present review is based on the references cited.

\section{References}

[1] Sanche S, Lin YT, Xu C, Romero-Severson E, Hengartner N, Ke R. Early release-high contagiousness and rapid spread of severe acute respiratory syndrome coronavirus 2. Emerg Infect Dis. 2020; 26:1470-7. 
[2] Sohrabi C, Alsafi Z, O’Neil N, Khan M, Kerwan A, Al-Jabir A, et al. World Health Organization declares global emergency: a review of the 2019 novel coronavirus (COVID-19). Int J Surg. 2020; 76:71-6.

[3] de Wit E, van Doremalen N, Falzarano D, Munster VJ. SARS and MERS: recent insights into emerging coronaviruses. Nat Rev Microbiol. 2016; 14:523-34.

[4] World Health Organization Coronavirus Disease (COVID-19) Dashboard [Internet]. Geneva: WHO; 2021 [cited 2021 Mar 24]. Available from: $h$ ttps://covid19.who.int

[5] Chou R, Dana T, Buckley DI, Selph S, Fu R, Totten AM. Epidemiology of and risk factors for coronavirus infection in health care workers: a living rapid review. Ann Intern Med. 2020; 173:120-36.

[6] Flaxman S, Mishra S, Gandy A, Unwin HJT, Mellan TA, Coupland $\mathrm{H}$, et al. Estimating the effects of non-pharmaceutical interventions on COVID-19 in Europe. Nature. 2020; 584(7820):257-61.

[7] World Health Organization R\&D Blueprint team. Draft landscape and tracker of COVID-19 candidate vaccines (database) [Internet]. Geneva: WHO; 2021 [cited 2021 March 24]. Available from: https://www.who.int/publications/m/item/draft-landscape-of-covid19-candidate-vaccines

[8] Lurie N, Saville M, Hatchett R, Halton J. Developing Covid-19 vaccines at pandemic speed. N Engl J Med. 2020; 382:1969-73.

[9] Torreele E. The rush to create a covid-19 vaccine may do more harm than good. BMJ. 2020; 370:m3209. doi: 10.1136/bmj.m3209.

[10] Alderman C. Special pharmacy challenges for older people in difficult times. Sr Care Pharm. 2020; 35:108-9.

[11] Soubeyrand B. [From vaccine manufacturing to its availability in pharmacy]. Rev Mal Respir. 2018; 35:1005-19. [French, English abstract]

[12] International Pharmaceutical Federation: an overview of current pharmacy impact on immunisation: a global report 2016. The Hague: FIP; 2016.

[13] Chowdhury MA, Hossain N, Kashem MA, Shahid MA, Alam A. Immune response in COVID-19: a review. J Infect Public Health 2020; 13:1619-29.

[14] Van Vinh Chau N, Lam VT, Dung NT, Yen LM, Minh NNQ, Hung LM, et al.; Oxford University Clinical Research Unit COVID-19 Research Group. The natural history and transmission potential of asymptomatic SARS-CoV-2 infection. Clin Infect Dis. 2020; 71:2679-87.

[15] Poletti P, Tirani M, Cereda D, Trentini F, Guzzetta G, Sabatino G, et al.; ATS Lombardy COVID-19 Task Force. Association of age with likelihood of developing symptoms and critical disease among close contacts exposed to patients with confirmed SARS-CoV-2 infection in Italy. JAMA Netw Open. 2021; 4:e211085. doi: 10.1001/ jamanetworkopen.2021.1085

[16] Long Q-X, Tang X-J, Shi Q-L, Li Q, Deng H-J, Yuan J, et al. Clinical and immunological assessment of asymptomatic SARS-CoV-2 infections. Nat Med. 2020; 26:1200-4.

[17] Sungnak W, Huang N, Bécavin C, Berg M, Queen R, Litvinukova $\mathrm{M}$, et al. SARS-CoV-2 entry factors are highly expressed in nasal epithelial cells together with innate immune genes. Nat Med. 2020; 26:681-7.

[18] Zou X, Chen K, Zou J, Han P, Hao J, Han Z. Single-cell RNA-seq data analysis on the receptor ACE2 expression reveals the potential risk of different human organs vulnerable to $2019-\mathrm{nCoV}$ infection. Front Med. 2020; 14:185-92.
[19] Prompetchara E, Ketloy C, Palaga T. Immune responses in COVID-19 and potential vaccines: lessons learned from SARS and MERS epidemic. Asian Pac J Allergy Immunol. 2020; 38:1-9.

[20] Merad M, Martin JC. Pathological inflammation in patients with COVID-19: a key role for monocytes and macrophages. Nat Rev Immunol. 2020; 20:355-62.

[21] Blanco-Melo D, Nilsson-Payant BE, Liu W-C, Uhl S, Hoagland D, Møller R, et al. Imbalanced host response to SARS-CoV-2 drives development of COVID-19. Cell. 2020; 181:1036-45.e9

[22] Zhou F, Yu T, Du R, Fan G, Liu Y, Liu Z, et al. Clinical course and risk factors for mortality of adult inpatients with COVID-19 in Wuhan, China: a retrospective cohort study. Lancet. 2020; 395(10229):1054-62.

[23] Linton NM, Kobayashi T, Yang Y, Hayashi K, Akhmetzhanov AR, Jung S-M, et al. Incubation period and other epidemiological characteristics of 2019 novel coronavirus infections with right truncation: a statistical analysis of publicly available case data. J Clinl Med. 2020; 9:538. doi: 10.3390/jcm9020538

[24] Ni L, Ye F, Cheng M-L, Feng Y, Deng Y-Q, Zhao H, et al Detection of SARS-CoV-2-specific humoral and cellular immunity in COVID-19 convalescent individuals. Immunity. 2020; 52:971-7.

[25] Grifoni A, Weiskopf D, Ramirez SI, Mateus J, Dan JM, Moderbacher CR, et al. Targets of $\mathrm{T}$ cell responses to SARS-CoV-2 coronavirus in humans with COVID-19 disease and unexposed individuals. Cell. 2020; 181:1489-1501.

[26] Seow J, Graham C, Merrick B, Acors S, Pickering S, Steel KJA, et al. Longitudinal evaluation and decline of antibody responses in the three months following SARS-CoV-2 infection in humans. Nat Microbiol. 2020; 5:1598-607.

[27] Pollock AM, Lancaster J. Asymptomatic transmission of covid-19. BMJ. 2020; 371:m4851. doi: 10.1136/bmj.m4851

[28] Ip DKM, Lau LLH, Leung NHL, Fang VJ, Chan K-H, Chu DKW, et al. Viral shedding and transmission potential of asymptomatic and paucisymptomatic influenza virus infections in the community. Clin Infect Dis. 2017; 64:736-42.

[29] Walls AC, Park Y-J, Tortorici MA, Wall A, McGuire AT, Veesler D. Structure, function, and antigenicity of the SARS-CoV-2 spike glycoprotein. Cell. 2020; 181:281-92.e6.

[30] To KK-W, Tsang OT-Y, Leung W-S, Tam AR, Wu T-C, Lung DC, et al. Temporal profiles of viral load in posterior oropharyngeal saliva samples and serum antibody responses during infection by SARS-CoV-2: an observational cohort study. Lancet Infect Dis. 2020; 20:565-74.

[31] Sariol A, Perlman S. Lessons for COVID-19 immunity from other coronavirus infections. Immunity. 2020; 53:248-63.

[32] Tay MZ, Poh CM, Rénia L, MacAry PA, Ng LF. The trinity of COVID-19: immunity, inflammation and intervention. Nat Rev Immunol. 2020; 20:363-74.

[33] Chen K, Kolls JK. T Cell-mediated host immune defenses in the lung. Annu Rev Immunol. 2013; 31:605-33.

[34] Arunachalam PS, Charles TP, Joag V, Bollimpelli VS, Scott MK, Wimmers F, et al. T cell-inducing vaccine durably prevents mucosal SHIV infection even with lower neutralizing antibody titers. Nat Med. 2020; 26:932-40.

[35] Moderbacher CR, Ramirez SI, Dan JM, Grifoni A, Hastie $\mathrm{KM}$, Weiskopf D, et al. Antigen-specific adaptive immunity to SARS-CoV-2 in acute COVID-19 and associations with age and disease severity. Cell. 2020. 183:996-1012.e19. 
[36] Remy KE, Mazer M, Striker DA, Ellebedy AH, Walton AH, Unsinger J, et al. Severe immunosuppression and not a cytokine storm characterizes COVID-19 infections. JCI Insight. 2020; 5:e140329. doi: 10.1172/jci.insight.140329

[37] Zhao J, Zhao J, Mangalam AK, Channappanavar R, Fett C, Meyerholz DK, et al. Airway memory $\mathrm{CD} 4^{+} \mathrm{T}$ cells mediate protective immunity against emerging respiratory coronaviruses. Immunity. 2016; 44:1379-91.

[38] Janice Oh H-L, Ken-En Gan S, Bertoletti A, Tan Y-J. Understanding the $\mathrm{T}$ cell immune response in SARS coronavirus infection. Emerg Microbes Infect. 2012;1:e23. doi: 10.1038/emi.2012.26

[39] Haq K, McElhaney JE. Immunosenescence: influenza vaccination and the elderly. Curr Opin Immunol. 2014; 29:38-42.

[40] Braun J, Loyal L, Frentsch M, Wendisch D, Georg P, Kurth F, et al. SARS-CoV-2-reactive T cells in healthy donors and patients with COVID-19. Nature. 2020; 587(7833):270-4.

[41] Jeyanathan M, Afkhami S, Smaill F, Miller MS, Lichty BD, Xing Z. Immunological considerations for COVID-19 vaccine strategies. Nat Rev Immunol. 2020; 20:615-32.

[42] Buchholz UJ, Bukreyev A, Yang L, Lamirande EW, Murphy BR, Subbarao K, Collins PL. Contributions of the structural proteins of severe acute respiratory syndrome coronavirus to protective immunity. Proc Natl Acad Sci U S A. 2004; 101:9804-9.

[43] Rauch S, Jasny E, Schmidt KE, Petsch B. New vaccine technologies to combat outbreak situations. Front Immunol. 2018; 9:1963. doi: 10.3389/fimmu.2018.01963

[44] Jeyanathan M, Yao Y, Afkhami S, Smaill F, Xing Z. New tuberculosis vaccine strategies: taking aim at un-natural immunity. Trends Immunol. 2018; 39:419-33.

[45] Afkhami S, Yao Y, Xing Z. Methods and clinical development of adenovirus-vectored vaccines against mucosal pathogens. Mol Ther Meth Clin Dev. 2016; 3:16030. doi: 10.1038/mtm.2016.30

[46] Szabo PA, Miron M, Farber DL. Location, location, location: tissue resident memory T cells in mice and humans. Sci Immunol. 2019; 4:eaas9673. doi: 10.1126/sciimmunol.aas 9673

[47] Wouters-Wesseling W, Rozendaal M, Snijder M, Graus Y, Rimmelzwaan G, de Groot L, Bindels J. Effect of a complete nutritional supplement on antibody response to influenza vaccine in elderly people. J Gerontol A Biol Sci Med Sci. 2002; 57:M563-6.

[48] Ventura MT, Casciaro M, Gangemi S, Buquicchio R. Immunosenescence in aging: between immune cells depletion and cytokines up-regulation. Clin Mol Aller. 2017; 15:21. doi: 10.1186/s12948-0170077-0

[49] Savy M, Edmond K, Fine PE, Hall A, Hennig BJ, Moore SE, et al. Landscape analysis of interactions between nutrition and vaccine responses in children. J Nutr. 2009; 139:2154S-218S.

[50] Arvas A. Vaccination in patients with immunosuppression. Turk Pediatri Ars. 2014; 49:181-5.

[51] Keusch GT. Nutritional effects on response of children in developing countries to respiratory tract pathogens: implications for vaccine development. Rev Infect Dis. 1991; 13(Suppl 6):S486-91.

[52] Opal SM, Girard TD, Ely EW. The immunopathogenesis of sepsis in elderly patients. Clin Infect Dis. 2005; 41:S504-12.

[53] Eliakim A, Swindt C, Zaldivar F, Casali P, Cooper DM. Reduced tetanus antibody titers in overweight children. Autoimmunity. 2006; 39:137-41.
[54] Călina D, Roşu L, Roşu AF, Ianoşi G, Ianoşi S, Zlatian O, et al. Etiological diagnosis and pharmacotherapeutic management of parapneumonic pleurisy. Farmacia. 2016; 64:946-52.

[55] DeStefano F, Bodenstab HM, Offit PA. Principal controversies in vaccine safety in the United States. Clin Infect Dis. 2019; 69:726-31.

[56] Plotkin S, Robinson JM, Cunningham G, Iqbal R, Larsen S. The complexity and cost of vaccine manufacturing - an overview. Vaccine. 2017; 35:4064-71.

[57] Pronker ES, Weenen TC, Commandeur H, Claassen EHJH, Osterhaus ADME. Risk in vaccine research and development quantified. PloS One. 2013; 8:e57755. doi: 10.1371/journal. pone.0057755

[58] Goetz KB, Pfleiderer M, Schneider CK: First-in-human clinical trials with vaccines-what regulators want. Nat Biotechnol. 2010; 28:910-6.

[59] Guerra Mendoza Y, Garric E, Leach A, Lievens M, Ofori-Anyinam O, Pirçon J-Y, et al. Safety profile of the RTS, S/AS01 malaria vaccine in infants and children: additional data from a phase III randomized controlled trial in sub-Saharan Africa. Hum Vaccin Immunother. 2019; 15:2386-98.

[60] Peeples L. News Feature: Avoiding pitfalls in the pursuit of a COVID-19 vaccine. Proc Natl Acad Sci U S A. 2020; 117:8218-21.

[61] Grenham A, Villafana T. Vaccine development and trials in low and lower-middle income countries: key issues, advances and future opportunities. Hum Vaccin Immunother. 2017; 13:2192-9.

[62] Almazán F, DeDiego ML, Sola I, Zuñiga S, Nieto-Torres JL, Marquez-Jurado S, Andrés G, Enjuanes L: Engineering a replication-competent, propagation-defective Middle East respiratory syndrome coronavirus as a vaccine candidate. mBio. 2013; 4:e00650-13. doi: 10.1128/mBio.00650-13

[63] Hou Y, Meulia T, Gao X, Saif LJ, Wang Q. Deletion of both the tyrosine-based endocytosis signal and the endoplasmic reticulum retrieval signal in the cytoplasmic tail of spike protein attenuates porcine epidemic diarrhea virus in pigs. J Virol. 2019; 93:e1758-18. doi: 10.1128/JVI.01758-18

[64] Jimenez-Guardeño JM, Regla-Nava JA, Nieto-Torres JL, DeDiego ML, Castaño-Rodriguez C, Fernandez-Delgado R, et al. Identification of the mechanisms causing reversion to virulence in an attenuated SARS-CoV for the design of a genetically stable vaccine. PLoS Pathog. 2015; 11:e1005215. doi: 10.1371/journal.ppat.1005215

[65] Tao Y, Shi M, Chommanard C, Queen K, Zhang J, Markotter W, et al. Surveillance of bat coronaviruses in Kenya identifies relatives of human coronaviruses NL63 and 229E and their recombination history. J Virol. 2017; 91:e01953-16. doi: 10.1128/JVI.01953-16

[66] ul Qamar MT, Saleem S, Ashfaq UA, Bari A, Anwar F, Alqahtani S. Epitope-based peptide vaccine design and target site depiction against Middle East respiratory syndrome coronavirus: an immune-informatics study. J Transl Med. 2019; 17:362. doi: 10.1186/s12967-019-2116-8

[67] Watanabe Y, Allen JD, Wrapp D, McLellan JS, Crispin M. Site-specific glycan analysis of the SARS-CoV-2 spike. Science. 2020; 369(6501):330-3.

[68] Murdin AD, Barreto L, Plotkin S. Inactivated poliovirus vaccine: past and present experience. Vaccine. 1996; 14:735-46.

[69] Vellozzi C, Burwen DR, Dobardzic A, Ball R, Walton K, Haber P. Safety of trivalent inactivated influenza vaccines in adults: background for pandemic influenza vaccine safety monitoring. Vaccine. 2009; 27:2114-20. 
[70] Wood JM, Robertson JS. From lethal virus to life-saving vaccine: developing inactivated vaccines for pandemic influenza. Nat Rev Microbiol. 2004; 2:842-7.

[71] Wang H, Zhang Y, Huang B, Deng W, Quan Y, Wang W, Xu W, Zhao Y, Li N, Zhang J. Development of an inactivated vaccine candidate, BBIBP-CorV, with potent protection against SARS-CoV-2. Cell. 2020; 182:713-21.

[72] Gao Q, Bao L, Mao H, Wang L, Xu K, Yang M, et al. Development of an inactivated vaccine candidate for SARS-CoV-2. Science. 2020; 369(6499):77-81.

[73] Xia S, Duan K, Zhang Y, Zhao D, Zhang H, Xie Z, et al. Effect of an inactivated vaccine against SARS-CoV-2 on safety and immunogenicity outcomes: interim analysis of 2 randomized clinical trials. JAMA. 2020; 324:951-60.

[74] Brennan Z, Paun C, Ehley B, Hilton J, Turcotte M, Morello L. The vaccines that could stop Covid-19 [Internet]. Arlington, VA: Politico; 2021 [cited 2021 March 24]. Available from: https://www. politico.com/interactives/2020/coronavirus-vaccine-tracker/

[75] Zeng L. Mucosal adjuvants: opportunities and challenges. Hum Vaccin Immunother. 2016; 12:2456-8.

[76] Zhu F-C, Li Y-H, Guan X-H, Hou L-H, Wang W-J, Li J-X, et al. Safety, tolerability, and immunogenicity of a recombinant adenovirus type- 5 vectored COVID-19 vaccine: a dose-escalation, open-label, non-randomised, first-in-human trial. Lancet. 2020; 395(10240):1845-54.

[77] Zhang S, Huang W, Zhou X, Zhao Q, Wang Q, Jia B. Seroprevalence of neutralizing antibodies to human adenoviruses type- 5 and type-26 and chimpanzee adenovirus type- 68 in healthy Chinese adults. J Med Virol. 2013; 85:1077-84.

[78] National Center for Immunization and Respiratory Diseases (NCIRD), Division of Viral Diseases. Different COVID-19 vaccines [Internet]. Atlanta, GA: Centers for Disease Control and Prevention. U.S. Department of Health \& Human Services; 2021 [cited 2021 March 24]. Available from: https://www.cdc.gov/ coronavirus/2019-ncov/vaccines/different-vaccines.html

[79] Corbett KS, Edwards D, Leist SR, Abiona OM, Boyoglu-Barnum S, Gillespie RA, et al. SARS-CoV-2 mRNA vaccine design enabled by prototype pathogen preparedness. Nature. 2020; 586(7830):567-71.

[80] Anderson EJ, Rouphael NG, Widge AT, Jackson LA, Roberts PC, Makhene M, et al. Safety and immunogenicity of SARS-CoV-2 mRNA-1273 vaccine in older adults. N Engl J Med. 2020; 383:2427-38

[81] Walsh EE, Frenck RW Jr, Falsey AR, Kitchin N, Absalon J, Gurtman A, et al. Safety and immunogenicity of two RNA-based Covid-19 vaccine candidates. N Engl J Med. 2020; 383:2439-50.

[82] Mulligan MJ, Lyke KE, Kitchin N, Absalon J, Gurtman A, Lockhart $\mathrm{S}$, et al. Phase I/II study of COVID-19 RNA vaccine BNT162b1 in adults. Nature 2020: 586(7830):589-93.

[83] Sahin U, Muik A, Derhovanessian E, et al. COVID-19 vaccine BNT162b1 and $T_{H} 1$ T cell responses. Nature. 2020; 586(7830):594-9.

[84] Del Giudice G, Rappuoli R, Didierlaurent AM: Correlates of adjuvanticity: a review on adjuvants in licensed vaccines. Semin Immunol. 2018; 39:14-21.

[85] HogenEsch H, O'Hagan DT, Fox CB. Optimizing the utilization of aluminum adjuvants in vaccines: you might just get what you want. NPJ Vaccines. 2018; 3:51. doi: 10.1038/s41541-018-0089-x

[86] Humphreys IR, Sebastian S. Novel viral vectors in infectious diseases. Immunol. 2018; 153:1-9.
[87] Draper SJ, Heeney JL. Viruses as vaccine vectors for infectious diseases and cancer. Nat Rev Microbiol. 2010; 8:62-73.

[88] Buchbinder SP, McElrath MJ, Dieffenbach C, Corey L. Use of adenovirus type- 5 vectored vaccines: a cautionary tale. Lancet. 2020; 396(10260):e68-9. doi: 10.1016/S0140-6736(20)32156-5.

[89] Colloca S, Barnes E, Folgori A, Ammendola V, Capone S, Cirillo A, et al. Vaccine vectors derived from a large collection of simian adenoviruses induce potent cellular immunity across multiple species. Sci Transl Med. 2012; 4:115ra2. doi: 10.1126/ scitranslmed.3002925

[90] Baden LR, Walsh SR, Seaman MS, Tucker RP, Krause KH, Patel A, et al. First-in-human evaluation of the safety and immunogenicity of a recombinant adenovirus serotype 26 HIV-1 Env vaccine (IPCAVD 001). J Infect Dis. 2013; 207:240-7.

[91] Anywaine Z, Whitworth H, Kaleebu P, Praygod G, Shukarev G, Manno D, Kapiga S, Grosskurth H, Kalluvya S, Bockstal V: Safety and immunogenicity of a 2-dose heterologous vaccination regimen with Ad26.ZEBOV and MVA-BN-Filo Ebola vaccines: 12-month data from a phase 1 randomized clinical trial in Uganda and Tanzania. J Infect Dis. 2019; 220:46-56.

[92] Mercado N, Zahn R, Wegmann F, Loos C, Chandrashekar A, Yu $\mathrm{J}$, et al. Single-shot Ad26 vaccine protects against SARS-CoV-2 in rhesus macaques. Nature. 2020; 586(7830):583-8.

[93] Folegatti PM, Ewer KJ, Aley PK, Angus B, Becker S, BelijRammerstorfer S, et al. Safety and immunogenicity of the ChAdOxl nCoV-19 vaccine against SARS-CoV-2: a preliminary report of a phase $1 / 2$, single-blind, randomised controlled trial. Lancet. 2020; 396:467-78.

[94] Wise J. Covid-19: European countries suspend use of OxfordAstraZeneca vaccine after reports of blood clots BMJ. 2021; 372:n699. doi: 10.1136/bmj.n699

[95] van Doremalen N, Lambe T, Spencer A, Belij-Rammerstorfer S, Purushotham JN, Port JR, et al. ChAdOx1 nCoV-19 vaccination prevents SARS-CoV-2 pneumonia in rhesus macaques. Nature. 2020; 586(7830):578-82.

[96] Henao-Restrepo AM, Camacho A, Longini IM, Watson CH, Edmunds WJ, Egger M, et al. Efficacy and effectiveness of an rVSV-vectored vaccine in preventing Ebola virus disease: final results from the Guinea ring vaccination, open-label, clusterrandomised trial (Ebola Ça Suffit!) Lancet. 2017; 389(10068): 505-18.

[97] Case JB, Rothlauf PW, Chen RE, Kafai NM, Fox JM, Smith BK, et al. Replication-competent vesicular stomatitis virus vaccine vector protects against SARS-CoV-2-mediated pathogenesis in mice. Cell Host Microbe. 2020; 28:465-74.e4.

[98] Yahalom-Ronen Y, Tamir H, Melamed S, Politi B, Shifman O, Achdout $\mathrm{H}$, et al. A single dose of recombinant VSV- $\Delta \mathrm{G}$-spike vaccine provides protection against SARS-CoV-2 challenge. Nat Commun. 2020; 11:6402. doi: 10.1038/s41467-020-20228-7

[99] Mou H, Raj VS, Van Kuppeveld FJ, Rottier PJ, Haagmans BL, Bosch BJ. The receptor binding domain of the new Middle East respiratory syndrome coronavirus maps to a 231-residue region in the spike protein that efficiently elicits neutralizing antibodies. J Virol. 2013; 87:9379-83.

[100] Guo Y, Sun S, Wang K, Zhang S, Zhu W, Chen Z. Elicitation of immunity in mice after immunization with the $\mathrm{S} 2$ subunit of the severe acute respiratory syndrome coronavirus. DNA Cell Biol. $2005 ; 24: 510-5$. 
[101] Zhou Y, Jiang S, Du L. Prospects for a MERS-CoV spike vaccine. Expert Rev. Vaccines. 2018; 17:677-86.

[102] Oscherwitz J. The promise and challenge of epitope-focused vaccines. Hum Vaccin Immunother. 2016; 12:2113-6.

[103] Du L, Zhao G, Chan CCS, Sun S, Chen M, Liu Z, et al. Recombinant receptor-binding domain of SARS-CoV spike protein expressed in mammalian, insect, and E. coli cells elicits potent neutralizing antibody and protective immunity. Virology. 2009; 393:144-50.

[104] Bolles M, Deming D, Long K, Agnihothram S, Whitmore A, Ferris $\mathrm{M}$, et al. A double-inactivated severe acute respiratory syndrome coronavirus vaccine provides incomplete protection in mice and induces increased eosinophilic proinflammatory pulmonary response upon challenge. J Virol. 2011; 85:12201-15.

[105] Diamond MS, Pierson TC. The challenges of vaccine development against a new virus during a pandemic. Cell Host Microbe. 2020; 27:699-703.

[106] Donaldson B, Lateef Z, Walker GF, Young SL, Ward VK. Virus-like particle vaccines: immunology and formulation for clinical translation. Expert Rev Vaccines. 2018; 17:833-49.

[107] Lu X, Chen Y, Bai B, Hu H, Tao L, Yang J, et al. Immune responses against severe acute respiratory syndrome coronavirus induced by virus-like particles in mice. Immunol. 2007; 122:496-502.

[108] Lokugamage KG, Yoshikawa-Iwata N, Ito N, Watts DM, Wyde PR, Wang N, et al. Chimeric coronavirus-like particles carrying severe acute respiratory syndrome coronavirus ( $\mathrm{SCoV}$ ) S protein protect mice against challenge with SCoV. Vaccine. 2008; 26:797-808.

[109] Naskalska A, Dabrowska A, Nowak P, Szczepanski A, Jasik K, Milewska A, et al. Novel coronavirus-like particles targeting cells lining the respiratory tract. PloS One. 2018; 13:e203489. doi: 10.1371/journal.pone.0203489

[110] Business Wire. Medicago announces positive results in animal trials for its vaccine candidate against COVID-19 [Internet]. San Francisco, CA: Berkshire Hathaway [cited 2021 March 24]. Available from: https://www.businesswire.com/news/home/20200514005745/ en/Medicago-Announces-Positive-Results-in-Animal-Trials-for-ItsVaccine-Candidate-Against-COVID-19

[111] Pardi N, Hogan MJ, Porter FW, Weissman D. mRNA vaccines-a new era in vaccinology. Nat Rev Drug Discov. 2018; 17:261-79.

[112] Lutz J, Lazzaro S, Habbeddine M, Schmidt KE, Baumhof P, Mui BL, et al. Unmodified mRNA in LNPs constitutes a competitive technology for prophylactic vaccines. NPJ vaccines. 2017; 2:29. doi: 10.1038/s41541-017-0032-6

[113] Hobernik D, Bros M. DNA vaccines-how far from clinical use? Int J Mol Sci. 2018; 19:3605. doi: 10.3390/ijms19113605
[114] Smith TR, Patel A, Ramos S, Elwood D, Zhu X, Yan J, et al. Immunogenicity of a DNA vaccine candidate for COVID-19. Nat Commun. 2020; 11:2601. doi: 10.1038/s41467-020-16505-0.

[115] Yu J, Tostanoski LH, Peter L, Mercado NB, McMahan K, Mahrokhian SH, et al. DNA vaccine protection against SARS-CoV-2 in rhesus macaques. Science. 2020; 369(6505): 806-11.

[116] Joint Committee on Vaccination and Immunisation: advice on priority groups for coronavirus (COVID-19) vaccination, 30 December 2020 [Internet]. London: Department of Health \& Social Care, UK Government. Contains public sector information licensed under the Open Government Licence v3.0; Crown, United Kingdom; 2020 [cited 2021 March 24]. Available from: https://www. gov.uk/government/publications/priority-groups-for-coronaviruscovid-19-vaccination-advice-from-the-jcvi-30-december-2020/ joint-committee-on-vaccination-and-immunisation-advice-onpriority-groups-for-covid-19-vaccination-30-december-2020

[117] Hassan-Smith Z, Hanif W, Khunti K. Who should be prioritised for COVID-19 vaccines? Lancet. 2020; 396(10264):1732-3.

[118] Holman N, Knighton P, Kar P, O’Keefe J, Curley M, Weaver A, et al. Risk factors for COVID-19-related mortality in people with type 1 and type 2 diabetes in England: a population-based cohort study. Lancet Diabetes Endocrinol. 2020; 8:823-33.

[119] Khunti K, Routen A, Patel K, Ali SN, Gill P, Banerjee A, et al. COVID-19 in black, Asian and minority ethnic populations: an evidence review and recommendations from the South Asian Health Foundation [Internet]. Leicester: South Asian Health Foundation; 2020 [cited 2021 March 24]. Available from: https://staticl.squarespace. com/static/5944e54ab3db2b94bb077ceb/t/5f059972f6680542c 546897f/1594202487799/Covid19_SAHF_Final+for+Release.pdf

[120] Clift AK, Coupland CAC, Keogh R, Diaz-Ordaz K, Williamson E, Harrison E, et al. Living risk prediction algorithm (QCOVID) for risk of hospital admission and mortality from coronavirus 19 in adults: national derivation and validation cohort study. BMJ. 2020; 371:m3731. doi: 10.1136/bmj.m3731

[121] World Health Organization Department of Communicable Disease Surveillance and Response. WHO guidelines on the use of vaccines and antivirals during influenza pandemics. [Internet] Geneva: WHO; 2004. [cited 2021 March 31]; Available from: $h t t p s: / /$ www.who.int/influenza/resources/documents/WHO_CDS_CSR_ RMD_2004_8/en/

[122] Lichty BD, Breitbach CJ, Stojdl DF, Bell JC. Going viral with cancer immunotherapy. Nat Rev Cancer. 2014; 14:559-67.

[123] Bollyky TJ, Gostin LO, Hamburg MA. The equitable distribution of COVID-19 therapeutics and vaccines. JAMA. 2020; 323:2462-3. 